\title{
Optimizing the Instructional Implementation of Islamic Education and Characters Based on the 2013- National Curriculum
}

\author{
Ujang Dedih \\ Department of Islamic Education \\ UIN Sunan Gunung Djati \\ Bandung, Indonesia \\ ujangdedih@uinsgd.ac.id
}

\author{
Dadan F Ramdhan \\ Department of Islamic Management Education \\ UIN Sunan Gunung Djati \\ Bandung, Indonesia \\ dadanramdhan74@uinsgd.ac.id
}

\author{
Nanang Kosim \\ Department of Arabic Education \\ UIN Sunan Gunung Djati \\ Bandung, Indonesia \\ nanang.kosim@uinsgd.ac.id
}

\begin{abstract}
This study aims to describe and analyze the implementation of learning Islamic Education and character in SMAN Bandung on the implementation aspect, the level of effectiveness of the 2013 curriculum of learning Islamic education and character in the curriculum 2013. The theoretical framework used in this study are Grand Theory and, Applied Theory. The methodology of this research is uses the qualitative approach with the descriptive analytic method. The techniques used in data collection is the study of documentation, observation, and interviews. Primary data sources consist of teachers and students. Secondary data sources consist of relevant books and government regulatory texts. The results can be concluded that. the level of effectiveness of curriculum implementation of 2013 Islamic Education and character subjects in Bandung city is very effective, on attitude competency aspect, knowledge and skill; Efforts to Optimize the Implementation of Curriculum 2013, namely: to include Islamic Education and character teachers in Bandung follow the education and professional practice of teachers; and Workshop Curriculum 2013 which is held by Bandung Ministry of Religion.
\end{abstract}

Keywords_Islamic Education; Characters

\section{INTRODUCTION}

Character education or character building is an integrated part of education in schools or family and environmental education. Islamic Education/ Pendidikan Agama Islam (PAI) and character have a big role in building the character of students in the school. The learning objectives that one of them form a good attitude and character become the main role in both subjects. Character problems can be a rapidly spreading issue as they relate to institutions, education in which there are learners, educators, educational practitioners and the ministry of education as the policy direction [1], [2] . Efforts to cultivate character education. The national policy of nation character building is based on the problems facing the nation today: (1) the disorientation and the unfolding of Pancasila values as the philosophy and ideology of the nation (2) The limitations of integrated policy instruments in realizing the essential values of Pancasila (3) The shift of ethical values in the life of the nation and the state (4) The waning of consciousness towards the nation's cultural values. (5) The threat of disintegration of the nation (6) The weakening of the nation's independence [3].

The education system in Indonesia is generally still focused on cognitive intelligence. This can be seen from the orientation of existing educational institutions are still preoccupied with the exam, ranging from midterms exam, final exam semester to national exam [4],[5]. It is time for policymakers, educators, parents and the community to enrich the perception that measures of success not only measure academic achievement, but educational institutions should always be a place to create an experience for learners to build and shape superior characters [5] .

To realize the strengthening of character education must be through planning, implementation, and evaluation of good and sustainable so that not only remember and understand but more than this seeks to make it happen. The curriculum of 2013 responds to problems related to the low level of students 'knowledge, the decline in student attitudes marked by negative behavior and students' awareness of themselves and others [6]. Curriculum 2013 has a philosophy of education based on noble values, academic value of learners and the community, because of improvement and balance of soft skills and hard skills that include aspects of attitude, skills, and knowledge [7]. Character building should be implemented comprehensively and continuously, the active role and concern of teachers in shaping the character of the students through example and teacher should be reflected in the teacher's behavior in the daily activities in the classroom [8]. Shaping the character of students cannot instantly but continuously create the conditions in the school and home environment that is comfortable, safe 
and conducive to the determinants of the success of the character of students, through the education of the negative behavior of students tend to decline [9], [4].

\section{RESEARCH METHODS}

This research uses a qualitative approach with the descriptive analytic method. Describing the condition of actual in school regarding academic or nonacademic activities that encourage the formation of character. The location of this research is three Senior High School/ Sekolah Menengah Atas SMAN in the city of Bandung namely: SMAN 3 Bandung, SMAN 10 Bandung and SMAN 26 Bandung, with the subject of this study are students of class XI and teachers PAI. The techniques used in data collection is the study of documentation, observation and interview students and teachers .Primary data sources consist of teachers and students. Secondary data sources consist of academic texts, journals, books, and government regulatory texts.

\section{RESULTS AND DISCUSSION}

\section{A. Level of Effectiveness and Outcomes Implementation Study PAI and Character}

Implementation of Curriculum 2013 subjects PAI and characters in SMAN 3, SMAN 10 and SMAN 26 Bandung tend to be implemented effectively this is due to the role of teachers and principals in encouraging the implementation of curriculum policy 2013. Indication a teachers want to improve profesionalism and learners active and creative in following the learning process. In the aspect of students' attitude competence in SMAN 3 Bandung tendency to increase this can be seen in the process of habituation or formers of the programmed attitude such as activities to read the Quran before reading the first hour, prayer, duha prayer, tadarus Al-Quran, tahsin/tahfidz, religious mentoring, Quran syarhil, calligraphy, Commemoration of the Great Muslim Day, fast pesantren, flag ceremony, nasyid, qosidah, and discipline of learning. In the aspect of knowledge competence after the enactment of the 2013 curriculum is very good, it is based on the acquisition of rat average value of learning achievement achievement of 97.50. While there are aspects of skills competence after the enactment of the 2013 curriculum is very good, this is based on the average achievement of learning achievement of 89.75 .

Competency attitude of students at SMAN 10 Bandung increased this can be seen in the process of habituation or forming attitudes that are programmed as reading and studying the Quran before starting the first hour, the Divine Name every Friday, the training speech / sermon / lecture, read a prayer daily prayers, tadarus Al-Quran, religious mentoring, Islamic Day of Commemoration, lightning pesantren, flag ceremony, nasyid, infaq every day that is distributed to ill and inadequate learners, and learning discipline. In the aspect of knowledge competence after the enactment of the 2013 curriculum is very good with the average achievement of learning achievement of 90 for science class and 86 for IPS class. In the aspect of competence attitude of students SMAN 26 Bandung tendency to increase this can be seen in the process of habituation or shaping attitudes programmed such as reading the Quran before starting to learn at the first hour, reading prayers, praying duha, tadarus Al-Quran, read Asmaul Husna, guidance tahsin / tahfidz, religious mentoring, PHBI, flag ceremony, and learning discipline. In the aspect of knowledge competence after the enactment of the 2013 curriculum is very high because it obtained the average grade of the final value of learning achievement of 82.5. In the aspect of skills competence with the enactment of the 2013 curriculum is very high because it obtained an average final value of 85 .

\section{B. Efforts Optimizing Learning PAI Implementation Character}

Planning and a good learning process will have implications for the achievement of learning objectives. The School continues to optimize the implementation of PAI and Character learning in the 2013 curriculum through various activities that encourage teacher professionalism improvement. Teachers can be said to run curriculum or curriculum implementers, without any significant role of teachers undoubtedly the implementation of the curriculum will not be achieved. Based on the interview to one of the teachers PAI research sites implementation of curriculum have 2013 said that the implementation of the curriculum in 2013 on the subjects of PAI and Character implemented smoothly. In the beginning is enforced the 2013 curriculum of teachers is confused, but after continuous training teachers understand the meaning and purpose of applying the curriculum 2013 through curriculum workshop on the application of scientific approach and authentic assessment. But not a bit of experience obstacle one of them has not been available books conform to the number of students remember the students must have handbook respectively, these problems can be resolved after the government print and distribute in the form of soft file teachers and learners can download and copy paper. According Principal Field Curriculum SMAN 26 City Bandung efforts to optimize the implementation of the 2013 curriculum is through:

The activities in the optimization of the implementation of PAI lessons and manners as follows:

- Conducting guidance to teachers including PAI and Character Teachers through teacher board meetings at least every 3 months and every moment required to provide motivation, direction and explanation of various things including receiving input and complaints of teachers on the implementation of curriculum which since 2013 enacted.

- Include PAI and morale teachers follow Technical Guidance (BIMTEK) 2013 curriculum organized by Ministry of Religious Affairs Bandung city.

- Includes PAI and Character teachers in 2013 curriculum facilitation activities organized by Ministry of Religion Affair Bandung city.

- Workshop Curriculum 2013 which is held by Ministry of Religious Affairs and organized by the Council Subject Teacher /Musyawarah Guru Mata Pelajaran (MGMP) Bandung.

- Organizing in house training on the 2013 curriculum organized by the school. 
- Including teachers of PAI and Character follow the Education and Training of Profession Teachers organized by the Faculty of Tarbiyah and Teacher Training UIN Sunan Gunung Djati Bandung in cooperation with the Ministry of Religious Affairs.

\section{CONCLUSION}

Implementation of Learning PAI and Character in Curriculum 2013 in SMAN Bandung so effective it get seen from the results of learning achievement in the aspect attitude, Knowledge and skill and output competency standard/ Standar Kompetensi Lulusan (SKL) Students SMAN Bandung very good. On average learning achievements gained 4.15 to dimension attitude religious and social. Knowledge Dimension obtained the average learning achievement of 90.3 and the average number of 84.58 for the skill dimension. Level of effectiveness optimization of curriculum implementation 2013 PAI and Character Subjects in Bandung city is very effective, on competency aspect, knowledge and skill due to active role of government and school in responding positively implementation of curriculum 2013.

\section{REFERENCES}

[1] T. Gray, "Character Education in Schools," ESSAI, p. 58, 2009.

[2] T. Lickona, Educating For Character, Bandung: Bandung Nusa Media, 2013.

[3] T. Penyusun, Kebijakan Nasional Pembangunan Karakter Bangsa Tahun 2010-2025, Jakarta, 2010.

[4] D. M. Dodds, "The Effects of Character Education on SocialEmotional Behavior," Masters of Arts in Education Action, p. 137, 2016.

[5] Hasanah, "Impelementasi Nilai-nilai Karakter Inti di Perguruan Tinggi," Jurnal Pendidikan Karakter, pp. 186-195, 2013.

[6] N. H. Abdurrahman, "CHARACTER EDUCATION IN ISLAMIC BOARDING SCHOOL- BASED SMA AMANAH," JPI, p. 287, 2016.

[7] T. Penyusun, Bahan Uji Publik Kurikulum 2013, Jakarta: Kemdikbud, 2012.

[8] H. Gunawan, Pendidikan Karakter Konsep dan Implementasi, Bandung: Alfabeta, 2014.

[9] N. C. o. Educational, Basic in Education, Newdelhi: Publication Divsion by the Secretary, National Council of Educational Research and Training, Sri Aurobindo Marg, 2014. 